AgNIESZKA ŚWIĘTEK

Pedagogical University of Krakow, Poland

\title{
The Importance of The Basics of Entrepreneurship as a School Subject in the Economic Preparation of the Young for their Professional Life
}

\begin{abstract}
The article aims to determine to what extent the implementation of the content of The Basics of Entrepreneurship can support young adults (those between 15 and 30 years old, according to the Central Statistical Office). It also investigates current reports on the economic situation of young adults in Poland and analyses the content of The Basics of Entrepreneurship's core curriculum. Diagnosis of their economic situation, based on these reports, has shown that Polish young adults are professionally active, though there is a high unemployment rate among them. Young adults plan to continue their education not necessarily in line with labour market requirements preferring to work in someone else's company, preferably as a member of a management team or a specialist, although they do not show too much commitment to their duties. The Basics of Entrepreneurship's core curriculum contains educational content that responds to these needs, although it is not always sufficiently detailed.
\end{abstract}

Keywords: Basics of Entrepreneurship; core curriculum; entering the labour market; young adults

Received: 16 January 2020

Accepted: 13 July 2020

\section{Suggested citation:}

Świętek, A. (2020). The Importance of The Basics of Entrepreneurship as a School Subject in the Economic Preparation of the Young for their Professional Life. Przedsiębiorczość - Edukacja [Entrepreneurship - Education], 16(2), 73-85. doi: 10.24917/20833296.162.6

\section{Introduction}

The role of entrepreneurship education in socio-economic development is significant, and The Basics of Entrepreneurship enables teachers to prepare school students for adult life (Rachwa1, 2005; Wach, 2013). This position is repeated quite often in academic studies on entrepreneurship education (Andrzejczyk, 2016; Borowiec-Gabryś, Kilar, Rachwał, 2018; Kilar, Rachwał, 2019; Świętek, 2018) and adopted as a theoretical assumption for research. 
The Basics of Entrepreneurship is a compulsory school subject at a secondary school. The reform of education in Poland currently being implemented has resulted in changes to the content of the core syllabi of all school subjects, including The Basics of Entrepreneurship (Rozporzadzenie Ministra Edukacji Narodowej...). However, for all school subjects, they are somewhat arbitrary. When developing them, teams of experts (academics, subject educators) select content from the achievements of the various fields represented in given school subjects, taking into account their educational value (cognitive, formative). "The subject of The Basics of Entrepreneurship is [...] a synthesis of deliberately selected elements of knowledge from the fields of economics, management and finance, enriched with elements of socio-economic geography, political science, sociology, psychology and law [...]" (Rozporzadzenie Ministra Edukacji Narodowej...: 16). The broad thematic scope of The Basics of Entrepreneurship and the limited time available for its implementation may lead school students to a cursory familiarisation with numerous socio-economic issues while losing the overarching goal which is the preparation (substantive, practical, educational) of young people for adult life.

The overall aim of this study is to determine to what extent entrepreneurship education, in its reformed version, can help young people start their adult working lives. In the article, the author focuses on the professional aspect because high professional and material status is the most crucial economic life goal indicated by the young themselves (Grabowska, Gwiazda, 2019). The author defines those between 15 and 30 years of age as "young adults". The specific objectives of the study are as follows:

- determination of the goals and plans of the young in adult life, the situation of young adults on the labour market, employment preferences and their attitudes towards work based on six nationwide research reports,

- indication of the content of The Basics of Entrepreneurship in its new core syllabus, the implementation of which corresponds to the needs identified from an analysis of reports.

In order to achieve the first goal, current national reports based on representative samples on the economic situation of young adults were investigated:

- Youth 2018 [Młodzież 2018] (Grabowska, Gwiazda, 2019) - a report prepared by CBOS and KBPN based on a 2018 survey of a random sample of 80 upper secondary schools - high schools, technical secondary schools and basic vocational schools - in 69 towns in Poland with a total sample of 1,609 students.

- Will we run out of leaders? Young experts enter the market [Czy zabraknie nam liderów? Młodzi eksperci wchodza na rynek] (2018) - Polish edition of the report First steps on the labour market [Pierwsze kroki na rynku pracy] prepared by Deloitte and based on a 2017 survey of a group of 2,508 young adults from six cities: Warsaw, Kraków, Poznań, Gdańsk, Katowice and Szczecin.

- The situation on the labour market for young adults in 2017 [Sytuacja na rynku pracy osób młodych w 2017 roku] (2018) - a report prepared by the Ministry for Family, Labour and Social Policy, Labour Market Department, based on a BAEL survey of young adults in various towns throughout Poland in 2017.

- Youth entrepreneurship survey report: national results [Raport badanie przedsiębiorczości wśród młodzieży. Wyniki ogólnopolskie] (2017) - prepared by the 'Academy of Leaders' based on a 2017 study of a group of 2,857 students from 39 upper secondary schools from various towns throughout Poland. 
- Young adults on the labour market: employees, entrepreneurs, unemployed [Młodzi na rynku pracy - pracownicy, przedsiębiorcy, bezrobotni] (2015).

- Labour market monitor [Monitor rynku pracy] (2019).

The results of the first four reports were analysed in detail due to the usefulness of the results they contained and the period of the research meaning only reports from 20172019 were used.

The second goal was achieved by analysing the content in the new core syllabus of The Basics of Entrepreneurship (Rozporzadzenie Ministra Edukacji Narodowej...) in terms of the presence of material corresponding to the economic needs of young adults.

\section{Goals of the young in adult life and the determinants of economic success}

When checking the hypothesis that The Basics of Entrepreneurship serves to prepare the young for adult life in its economic aspect, the first question that arises is what this life should be like. The author decided to base the analysis on the expectations of the young adults themselves. The report Youth 2018 (2019) presents the results of research into Polish youth from 2018 and previous years, 1994, 1996, 1998, 2003, 2008, 2010, 2013, 2016, concerning the essential goals of adult life (Figure 1). The results show that in the years 1994-2018 the young adults surveyed invariably indicated the same goals as the most important, what is more, their hierarchy remained unchanged.

In 2018 , half $(52 \%)$ of respondents indicated the most important being love and friendship, as well as successful family life and children $-42 \%$. In this case, the invariability of the hierarchy is in a way incompatible with the rapid generational (Making sense of..., 2015) and demographic changes in Poland in the last thirty years: a decrease in the marriage rate and the later age of marriage, a decrease in the fertility rate of women and the number of births (Stańczak et al., 2016).

From the research aim, further goals indicated by the young are more critical. The third is an exciting job in line with their interests - $40 \%$ of respondents, followed by achieving a high professional position and career (33\%) as well as wealth and achieving a high material situation (33\%) (Grabowska, Gwiazda, 2019). All the indicated goals are related to the professional future of young adults. The analysis of the content in the new core syllabus for The Basics of Entrepreneurship (Rozporzadzenie Ministra Edukacji Narodowej...) has shown that it contains many general education goals corresponding to this demand:

"I.2. understanding the essence of entrepreneurship and learning its role in the economy and human life

I.8. understanding the functioning of the labour market, the principles of active job search $[\ldots]$

II.4. responsible money management, analysing, evaluating and conscious using of financial services and investing capital [...]

II.6. raising personal and social competencies necessary on the labour market and strengthening motivation to work" (Rozporzadzenie Ministra Edukacji Narodowej...: 191, 192).

The implementation of the new assumptions of entrepreneurship education should also bring about a change in opinions on its importance in achieving these life goals. The report Youth 2018 (2019) shows that until now, they have not perceived entrepreneurship 
Figure 1 . The most important goals of the young for adulthood ( $\%$ of responses)

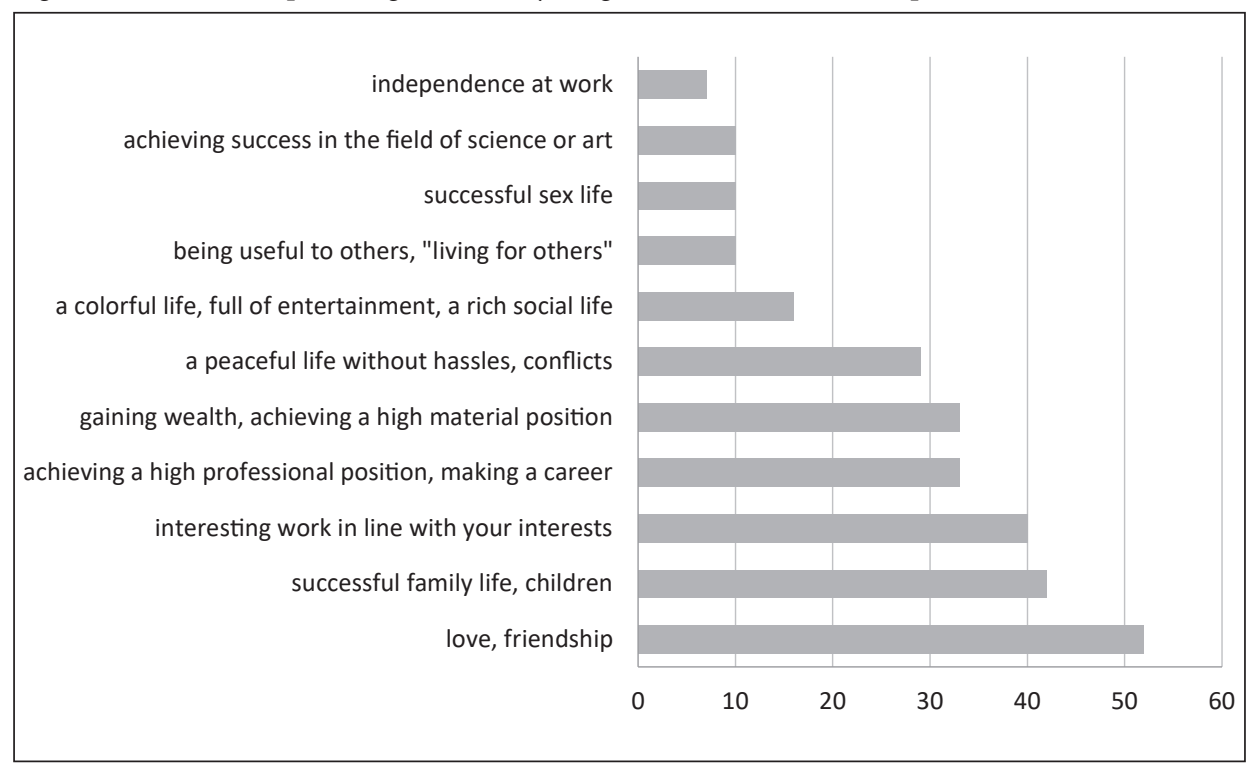

Source: based on the report Grabowska, Gwiazda (2019)

Figure 2. Determinants of economic success in adult life in the opinion of the young (\% of answers)

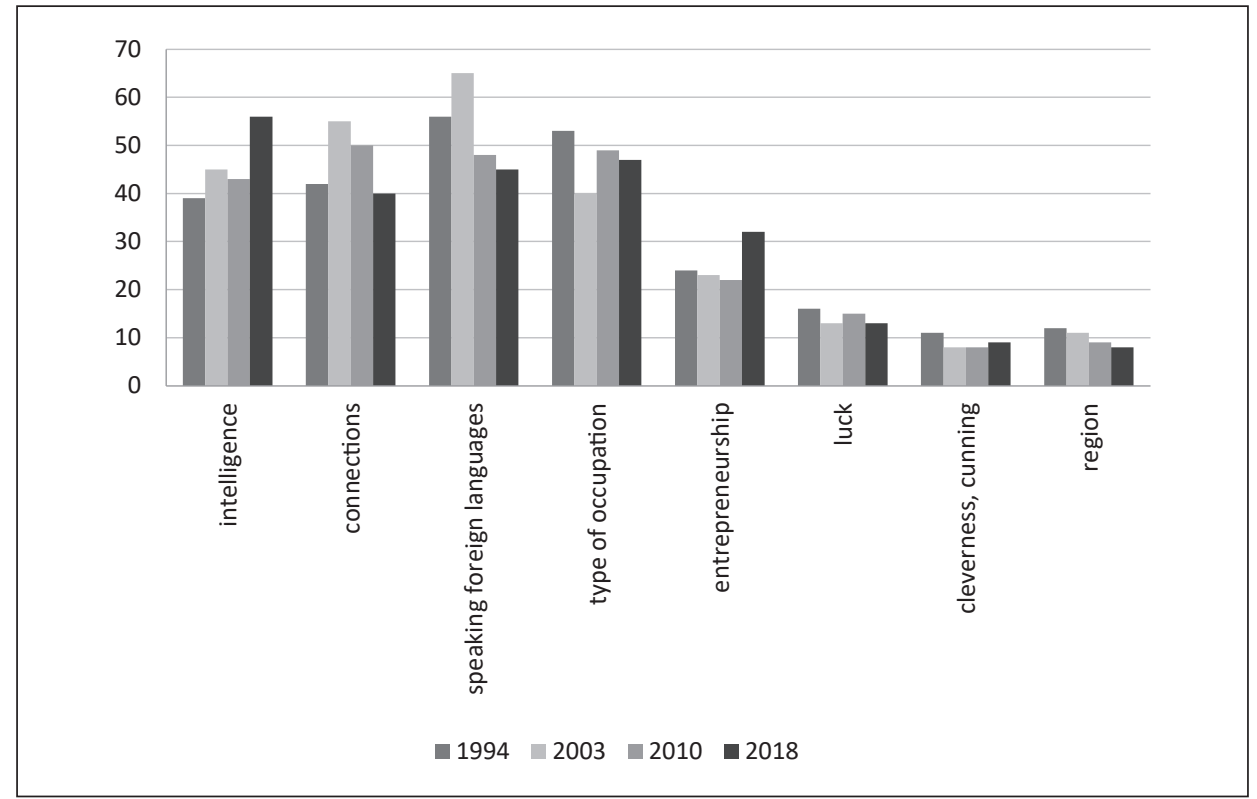

Source: based on the Młodzież 2018 (Grabowska, Gwiazda, 2019) report, which used CBOS data from 1994 and KBPN research from 2003, 2010, 2018 
as a significant factor for economic success (Figure 2). Their answers to the question What, in your opinion, determines economic success? showed that the most critical determinants in 2018 were intelligence (56\%), type of profession (47\%), language skills (45\%) and knowledge (40\%), and only then entrepreneurship (32\%). Knowledge of foreign languages is a particular criterion that is an essential condition for gaining a good professional position, presently and in the future (Świętek, 2018). Intelligence and connections are not going to help in the long term in the modern labour market if they are not related to an entrepreneurial attitude. Similarly, the type of profession, if it is wanted after graduation, after a few years may lack demand on the labour market, and only the entrepreneurial spirit of its owner may make adaptation appropriate to new market conditions (Świętek, 2018). The importance of entrepreneurship, although low in the opinion of the young, has increased in the analysed period (from 24\% in 1994 to $32 \%$ in 2018), as does the importance of intelligence, both opposite to the importance of the other determinants of economic success.

The response of the authors of the new core syllabus to the low importance of entrepreneurship is the following content:

"III.1. using the acquired economic knowledge to develop your entrepreneurial attitude as one of the necessary conditions for active participation in socio-economic life, including the adequate performance of contract work and running your own business

III.2. taking advantage of market opportunities, taking the initiative, inventiveness and the ability to overcome internal and external barriers

III.3. appreciating entrepreneurial attitudes in everyday life [...]" (Rozporzadzenie Ministra Edukacji Narodowej...: 192, 193).

\section{Young adults' plans for the future}

An essential aspect of preparing the young for adult life concerning entrepreneurship education goals is the support given to informed decision making when choosing a further educational and professional path.

According to the report Youth 2018 (2019), most young adults plan to continue their education at higher levels after secondary school (63\%) and among them, half want to combine it with work (32\%). Young adults who do not plan to study mainly want to start work in a state-owned or private enterprise (11\%), or go abroad (10\%). Only $5 \%$ of them plan to start their own business. Those who were planning to start their higher education wanted to study in the following fields: social sciences (30\%), technology (21\%), medical sciences, health and physical culture (15\%), humanities (8\%), science (7\%), in the field of art (6\%), the environment (5\%), agriculture, forestry and veterinary $(2 \%)$, other (1\%), while $5 \%$ did not know what to apply for (Grabowska, Gwiazda, 2019).

Forecasts of the demand for professions in the future, which are made by market research specialists in Poland based on contemporary trends in the economy, indicate that the most important in the next two decades will be IT specialists and programmers, project management leaders, representatives of engineering and technology fields (biotechnologists, mechatronics, production technologists), analysts, but also there will be those from more traditional professions: traders, physiotherapists, masseurs, trainers, nutritionists, builders and artisans (tailors, plumbers, tilers) (Business Insider Polska, 2020; 
Pracuj.pl). The career plans indicated by the young remain only partially compatible with market requirements in the future. The young plan their education in various fields according to their interests, and usually not concerned with demand on the labour market, as the mere fact of having higher education (regardless of the subject) objectively increases their chances on the labour market. The research by Jakimiuk (2017) demonstrates that the unemployment rate among young adults is inversely proportional to education, the higher the education, the lower the unemployment rate. However, they seem to be unaware of the devaluation of higher education in favour of the importance of the type of competencies held by an employee on the labour market (Świętek, 2012). This issue is evidenced by the demand for employees of traditional professions, not taken into account in occupational plans (Grabowska, Gwiazda, 2019; Świętek, 2012).

The new core syllabus for The Basics of Entrepreneurship (Rozporzadzenie Ministra Edukacji Narodowej...) assumes that supporting young adults in planning their further career and educational paths include the following educational objectives:

"III.3. [the student] recognises the motives of human professional activity and analyses the chances and possibilities of developing a professional career, noting the role of the lifelong learning process [...]

III.5. analyses own competencies and opportunities for gaining professional experience in the form of voluntary work, internships and finding a job on the local, regional, national or international markets" (Rozporzadzenie Ministra Edukacji Narodowej....: 195, 196).

\section{The situation of young adults in the labour market}

The situation on the labour market reveals the goals and plans of young adults they face as presented in the report "The situation on the labour market for young adults in 2017" (Sytuacja na rynku pracy..., 2018) by the Central Statistical Office, which includes their economic activity, the unemployment rate and the duration of unemployment.

Professional activity of the young in 2017 varied depending on their age. Young adults aged 15-24 showed low economic activity (35\%), mainly due to continuing education at higher levels; on the other hand, they showed high professional activity (84.4\%) compared to all Poles over 15 years of age who had completed formal education $-56.2 \%$ in 2017 (Sytuacja na rynku pracy..., 2018).

The unemployment rate (14.8\%) among adults aged 15-24 who had left education was high at the end of 2017 compared to the total number of adults over 15, which at that time was $4.5 \%$ (Sytuacja na rynku pracy..., 2018). The average duration of unemployment among young adults at the end of 2017 was 7.9 months, lower than among the total unemployed at 12.7 months.

The phenomenon of young adult unemployment and being unemployed is considered a serious problem and an economic and social threat (Sadowski, Kozłowski, 2010) "because it seriously hinders the young starting life and functioning in society, as well as their personal and professional development" (Jakimiuk, 2017: 194). The high unemployment rate among young adults is caused by several factors that can be divided into objective (demographic and economic situation and changes in the labour market) and subjective (approach to career, education, activity, ambition and expectations) (Rybicka, 2014). 
Objective factors are independent of the young person entering the labour market. On the other hand, subjective factors, depending on the individual, should be taken into account in the field of entrepreneurship education. The new core syllabus for The Basics of Entrepreneurship takes into account the educational objectives corresponding to this demand:

"III.2. [the student] explains the demand and supply mechanism in the labour market $[\ldots]$

III.3. recognises the motives of human professional activity and analyses the chances and possibilities of developing a professional career, noting the role of the lifelong learning process

III.4. distinguishes between job search methods and assesses their usefulness and effectiveness for a career development path

III.5. analyses competencies and opportunities to gain professional experience in the form of voluntary work, internships and finding a job on local, regional, national or international markets

III.6. prepares application documents for a specific job offer

III.7. prepares for an interview and participates in it in simulated conditions, emphasising its advantages and noticing the fundamental mistakes made during the interview" (Rozporzadzenie Ministra Edukacji Narodowej...).

\section{Employment preferences and young adults' attitude towards work}

In order to prepare the young to start their adult professional life, it is essential to take into account their employment preferences and to shape appropriate attitudes towards work. According to the report, "Will we run out of leaders? Young experts enter the market" (2018), in 2017 half of the young planned to work in someone else's company (51\%), and only $13 \%$ wanted to start their own business in the future. As many as one-third of the remaining respondents (36\%) did not know what their employment preferences were.

The core syllabus includes both educational goals related to searching for work in the labour market and preparation for starting an enterprise. The section on training in The Basics of Entrepreneurship devoted to contract work is Section III: Labour market. As part of it, students will:

- get to know the necessary measures and indicators of the labour market as well as the demand and supply mechanism in this market

- recognise the motives of the professional activity of adults and analyse opportunities for developing a professional career

- distinguish between job search methods and assess their usefulness and effectiveness for a career development path

- analyse own competencies and opportunities to gain professional experience and find a job

- develop application documents for a specific job offer and prepare for an interview

- distinguish between forms of employment, learn about the types of employment contracts, pay systems, types and forms of remuneration and calculate net remuneration

- learn about the rights and obligations of employee and employer, rules of work organisation as well as health and safety

- evaluate ethical and unethical behaviour of the employer and employees. 
The syllabus regarding the knowledge and skills to prepare young adults to enter the labour market are appropriate. However, an analysis of the economic reports shows that apart from them, close attention should also be paid to the approach of young adults to work and fulfilling their professional duties.

The research results show that only $39 \%$ of young adults who have already taken up employment engage $100 \%$ of their abilities in it (Figure 3). Most are not active at work and take no initiative (62\%). Only $23 \%$ of young employees devote themselves to professional duties, accepting the statement: 'I do what it takes to finish my work.' (Czy zabraknie nam liderów?..., 2018). Work also does not seem to be of value to most young adults. Only half of those surveyed feel satisfied after a day spent in intensive work (52\%), and only a third believe that thanks to hard work they can achieve more than others (33\%) (Czyzabraknie name liderów?..., 2018). For young employees of generation $Z$ (born after 1999) in the 'work-life balance', 'life' is much more important than 'work'. Their attitude is different from that of generation Y (born 1980-1998) and cannot be compared with that of generation X (1965-1979) or baby boomers (1945-1964). Half of the surveyed young adults believe that work cannot force them to give up other things (48\%) and should give them more free time for other activities and rest (32\%) (Czy zabraknie nam liderów?..., 2018).

The pragmatic approach of young adults also includes a lack of attachment to their employer, which makes them very different from previous generations of employees. In 2017, 35\% of employees aged 18-29 had changed jobs in the previous six months, and young employees changed jobs two to three times more often than those in other age groups (Czy zabraknie name liderów?..., 2018). Young adults often quitting jobs and looking for a new one is not considered the fault of the current employer as young workers are satisfied with them (80\%), much more than older workers. They decide to change

Figure 3. The attitude of young adults towards work in 2017 (\% of yes)

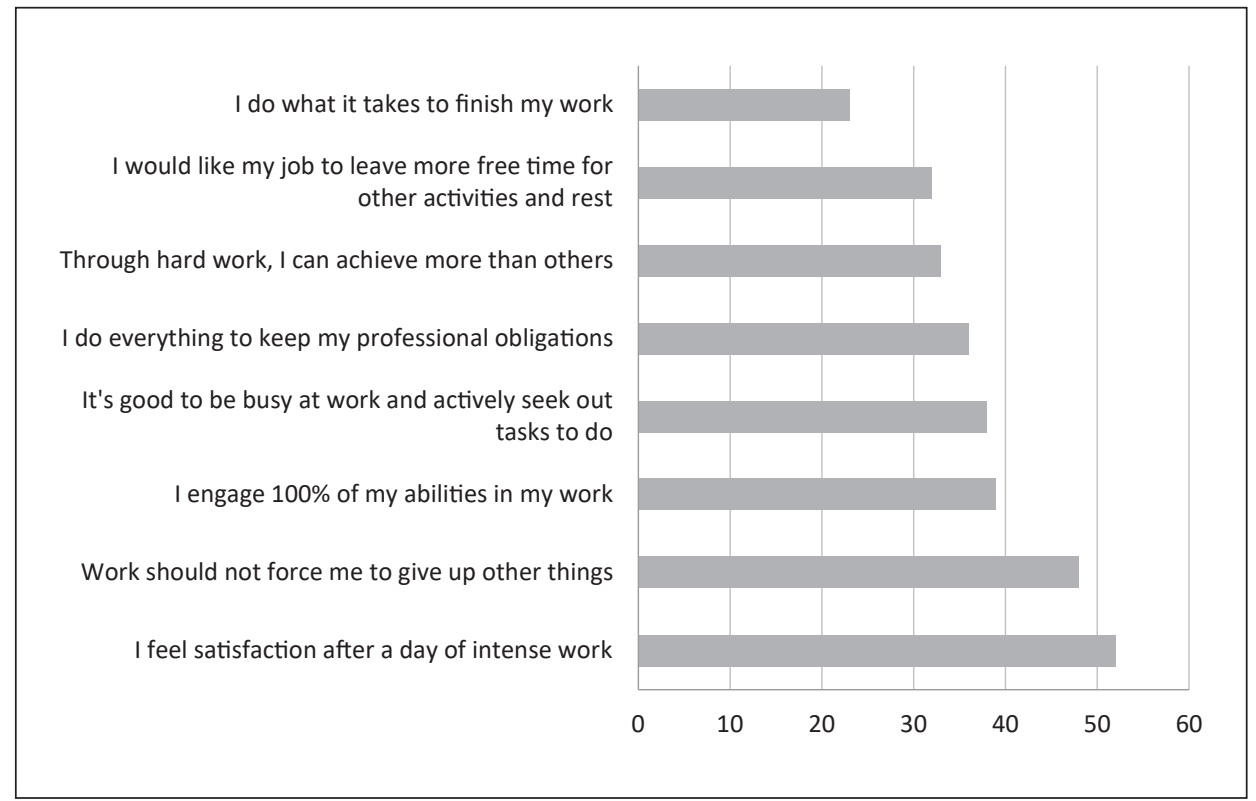

Source: based on the report: Czy zabraknie nam liderów?... (2018) 
jobs because they are convinced that they will find a better or at least an equally good job (79\%), and indeed any available job (92\%). This belief is favoured by the employee market, the currently very low unemployment rate in Poland (especially in large cities), and the financial security provided by their long-term dependency on their parents. The reasons for changing employer indicated by young employees are a higher salary at the new employer (55\%) and the desire for professional development (46\%) (Czy zabraknie name liderów?..., 2018). The protective financial umbrella of parents means that young adults are not afraid of losing their jobs and see numerous solutions to problems in finding one: enrolling on training courses (29\%), going abroad (26\%), or taking up any available job (19\%). To a lesser extent, the way out of a bad situation is for them to start their own business (12\%) or continue education (8\%) (Grabowska, Gwiazda, 2019). Family support, awareness of the good condition of the labour market and taking advantage of the opportunity to change jobs in order to achieve satisfaction by young adults is a positive phenomenon. However, it is essential that they appreciate the non-material importance of work, respect employers and honestly approach the performance of their duties. Education in The Basics of Entrepreneurship takes into account the general objectives responding to these needs:

"I.8. understanding the functioning of the labour market, the principles of active job search, preparation for a job interview, learning about the rights and obligations of the employee and the employer [...]

II.6. raising personal and social competencies necessary on the labour market and strengthening motivation to work

III.7. shaping responsible attitudes as future employees and employers and proper fulfilment of duties [...]

III.8. shaping proactivity, responsibility for oneself and others, and skilfully reconciling one's good with the good of other adults [...]

III.11. adopting ethical attitudes, social solidarity and responsibility in economic life" (Rozporzadzenie Ministra Edukacji Narodowej...).

Unfortunately, these general goals do not find their equivalents in the form of the specific content in individual sections of the core syllabus, so the author has doubts to what extent and in what form teachers in the classroom will implement them. Assumed in Section III: Labour market the specific objective "assessment of ethical and unethical behaviour" of employees and employers seems insufficient in the light of the reports.

The least popular professional preference among young adults is to start their own business. Apart from the mere fact of a low willingness to run one, the reasons for such an attitude are equally important. The results of research presented in the Report on entrepreneurship among young adults: national results (2017) indicate that the reluctance to start their own business is caused by an awareness of the lack of knowledge, experience and financial resources to start one. An equally important reason is their pragmatism, a realistic assessment of reality and taking only such actions that guarantee effectiveness (Figure 4).

The most important reason for the reluctance to start their own business in 2017 was the lack of a good business idea (45\%). Approximately one-third of those surveyed believe they do not have sufficient knowledge, experience and financial resources to start, and this would make them afraid to make such an attempt. About one-fifth declare that 
they do not know how to start a company, and 14\% do not know the sources of support for a newly established one (Raport badanie przedsiębiorczości wśród młodzieży, 2017), although according to the current core syllabus they have followed in The Basics of Entrepreneurship in secondary school they have.

An important factor causing a reluctance in young adults to start a business is the burden it carries. They do not want to run one because it is associated with living under stress $(30 \%)$, working overtime $(27 \%)$ and the need to control documentation and balance accounts (24\%) for which they are not predisposed (25\%) (Raport badanie przedsiębiorczości wśród młodzieży, 2017).

The Basics of Entrepreneurship is a subject which pays much attention to starting businesses. The previous and new core syllabus for The Basics of Entrepreneurship (Rozporzadzenie Ministra Edukacji Narodowej...) includes many educational goals, the implementation of which enable the young to prepare for establishing their own company. During entrepreneurship lessons, they acquire the knowledge and skills necessary to set up a business within Section IV: Enterprise by creating a business plan project. While working on this project, they are expected to achieve goals which include creating a business idea, getting to know the principles of record-keeping and accounting, and learning about the possibilities of support from various institutions, including all the content that, according to the report, young adults had indicated as reasons for their reluctance to start a company.

In the case of Section III: Labour market, there are no specific goals regarding attitudes towards contract work, and in Section IV: Enterprise, no specific goals shaping an appropriate attitude towards economic activity. Such goals broadly take into account the general assumptions of the subject, including:

"II.11. preparation for running your own business [...]

Figure 4 . The reasons for the reluctance of young adults to start their own business (\% of responses)

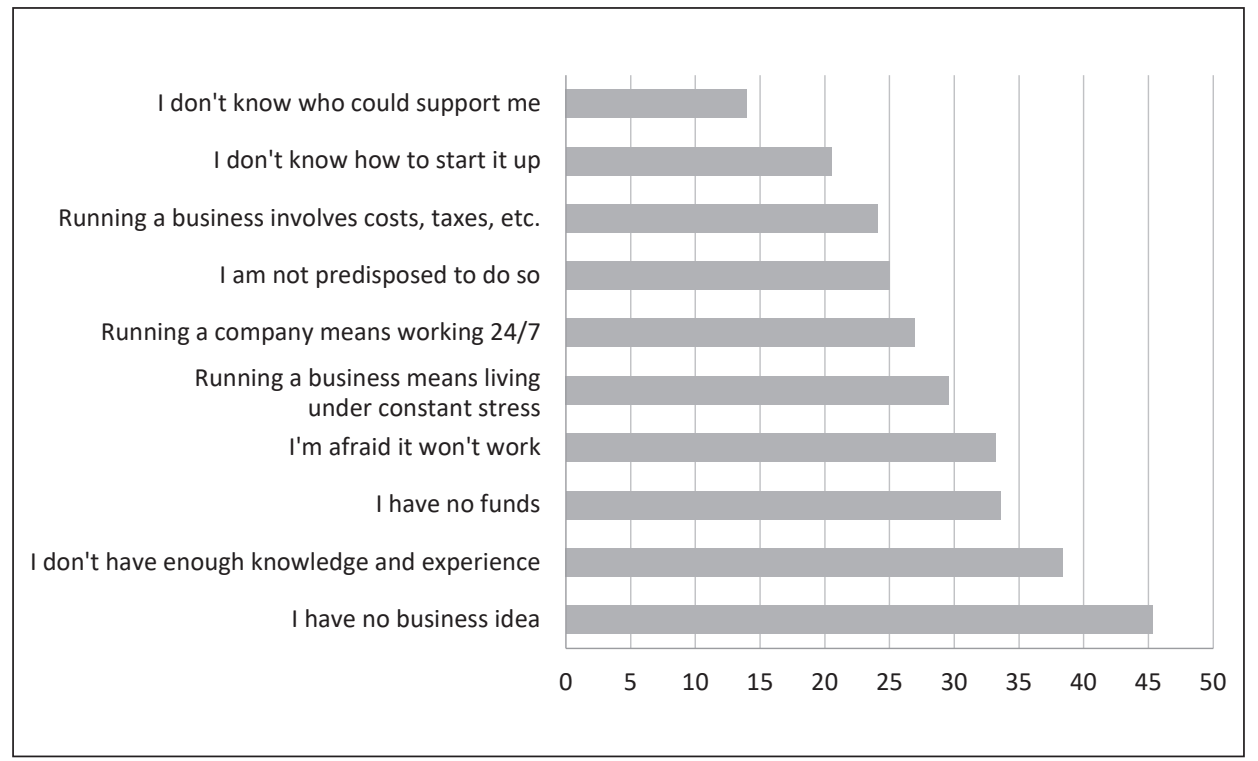

Source: based on Raport badanie przedsiębiorczości wśród młodziė̇y (2017) 
III.1. using the acquired economic knowledge to develop an entrepreneurial attitude [...] including the adequate performance of contract work and running a business

III.2. taking advantage of market opportunities, taking the initiative, inventiveness and the ability to overcome internal and external barriers

III.3. appreciating entrepreneurial attitudes in everyday life, readiness to actively participate in the socio-economic life of the country, and shared responsibility for its development

III.4. appreciating the role of entrepreneurs responsible for building a competitive economy and recognising the importance of economic freedom and private property as pillars of the market economy" (Rozporzadzenie Ministra Edukacji Narodowej...: 192,193).

The lack of specific educational content relating to shaping attitudes towards starting a business may result in the assumed general goals not being achieved in school practice.

\section{Summary}

"Contemporary civilisation poses new challenges and demanding tasks in education and preparation for fulfilling specific professional roles. The tasks are determined by social, economic and cultural development, the state of social awareness, and the needs and interests of adults living in specific socio-economic structures. They set the main priorities for educational policy and the structure of the education system" (Zioło, 1999: 127). According to current curriculum assumptions for education in Poland, based on the theory of personal pedagogy, school students are placed at the centre of the education process. Entrepreneurship education aims to prepare them for adult economic, and especially professional, life.

The analysis of research reports has revealed some aspects of the professional life of young adults which entrepreneurship education could support. They mainly concern the conscious planning of a professional and educational career path and the issue of attitudes towards work. The diagnosis of various aspects of the economic situation of young adults resulting from the reports showed that:

- young adults' economic goals have for years been associated with entering the labour market,

- the majority of young adults still choose fields of study in line with their interests, and not necessarily with the requirements of the labour market,

- young adults do not plan to start their own business but to perform contract work,

- young adults are professionally active, take up various forms of work, are willing to raise their competencies and change in search of professional satisfaction,

- young employees do not become attached to their employers and do not show much commitment to their duties.

The analysis of the content of the core syllabus for The Basics of Entrepreneurship has shown that it includes issues related to the needs of preparing the young for adult working life, but the level of detail varies considerably. They are included in general purposes as well as in specific content, mainly in Section III: Labour market and Section IV: Enterprise (Rozporzadzenie Ministra Edukacji Narodowej...). According to the author, each of the needs indicated in the reports should be reflected in a specific goal of The Basis of Entrepreneurship. Teachers may neglect the general objectives of education 
by being too general. The key is the correct interpretation of all the provisions of the core syllabus in order to use the implementation of its content to support the young in their start into adulthood.

\section{References}

Andrzejczyk, A. (2016). Metody badań edukacji przedsiębiorczej. Przedsiębiorczość - Edukacja [Entrepreneurship - Education], 12, 352-363.

Borowiec-Gabryś, M., Kilar, W., Rachwał, T. (2018). Przedsiębiorczość jako kompetencja przyszłości. In: S. Kwiatkowski (ed.), Kompetencje przyszłości. Warszawa: FRSE, 68-89.

Business Insider Polska. (2020, 2 January). Retrieved from: https://businessinsider.com.pl/rozwoj-osobisty/kariera/pracownicy-poszukiwani-w-2020-r/hsjbb7f

Czy zabraknie nam liderów? Młodzi eksperci wchodza na rynek. Polska edycja raportu Pierwsze kroki na rynku pracy. (2018).Warszawa: Deloitte.

Grabowska, M., Gwiazda, M. (red.). (2019). Młodzież 2018. Warszawa: CBOS, KBPN.

Jakimiuk, B. (2017). Bezrobocie wśród polskiej młodzieży i jego dynamika. Annales Universitatis Mariae Curie-Skłodowska, XXX, 193-203.

Kilar, W., Rachwał, T. (2019). Changes in Entrepreneurship Education in Secondary School under Curriculum Reform in Poland. Journal of Intercultural Management, 11(2), 73-105.

Making sense of a world in motion. (2015). United Kingdom: Ernst \& Young Global Limited.

Młodzi na rynku pracy - pracownicy, przedsiębiorcy, bezrobotni. (2015). Warszawa: PARP.

Monitor Rynku Pracy. Wyniki 36. edycji badania. (2019). Warszawa: Instytut Badawczy Randstad.

Praca.pl. (2020, 2 January). Retrieved from: https://www.praca.pl/poradniki/warto-wiedziec/ zawody-przyszlosci-2020-2030_pr-3546.html

Rachwał, T. (2005). Kształtowanie postaw uczniów na lekcjach podstaw przedsiębiorczości. Przedsiębiorczość - Edukacja [Entrepreneurship - Education], 1, 137-143.

Raport badanie przedsiębiorczości wśród młodzieży. Wyniki ogólnopolskie. (2017). Grodzisk Mazowiecki: Akademia Liderów.

Rozporzadzenie Ministra Edukacji Narodowej z dnia 30 stycznia 2018 r.w sprawie podstawy programowej kształcenia ogólnego dla liceum ogólnokształcacego technikum oraz branżowej szkoły II stopnia. Dz.U. z 2018 r., poz. 467.

Rybicka, K. (2014). Bezrobocie młodzieży w Polsce. Studia Ekonomiczne, 197, 195-201.

Sadowski, Z., Kozłowski, P. (2010). Zagrożenia ekonomiczno-społeczne. Nauka, 4, 23-29.

Stańczak, J., Stelmach, K., Urbanowicz, M. (2016). Małżeństwa oraz dzietność w Polsce. Warszawa: GUS. Sytuacja na rynku pracy osób młodych w 2017 roku. (2018). Warszawa: Ministerstwo Rodziny, Pracy i Polityki Społecznej, Departament Rynku Pracy, Wydział Analiz i Statystyki.

Świętek, A. (2018). Edukacja formalna na rzecz przedsiębiorczości wobec współczesnych wyzwań cywilizacyjnych. Horyzonty Wychowania, 17(44), 189-197.

Świętek, A. (2012). Oczekiwania a realia wejścia ludzi młodych na rynek pracy jako wyzwanie dla edukacji z przedsiębiorczości. Przedsiębiorczość - Edukacja [Entrepreneurship - Education], 8, 137-154.

Wach, K. (2013). Edukacja na rzecz przedsiębiorczości wobec współczesnych wyzwań cywilizacyjno-gospodarczych. Przedsiębiorczość - Edukacja [Entrepreneurship - Education], 9, 246-257.

Zioło, I. (1999). Wybrane atrybuty wartości edukacyjnej wyższej szkoły niepaństwowej. Zeszyty Naukowe Wyższej Szkoty Informatyki i Zarządzania w Rzeszowie, 3(3), 127-136.

Agnieszka Świętek, PhD in geography, graduated from Pedagogical University of Krakow MA degree in geography, specialisation in Entrepreneurship and spatial planning. Adjunct (assoc. professor) at the Pedagogical University of Krakow, Institute of Geography. Her research interests focus on two different research themes: the education in the field of geography and entrepreneurship, in 
particular the process of starting up own business, young adults entering into the labour market and the quality of life of Roma in Poland.

ORCID: https://orcid.org/0000-0002-5049-6476

\section{Address:}

Uniwersytet Pedagogiczny im. Komisji Edukacji Narodowej

Instytut Geografii

Katedra Badań nad Edukacją Geograficzną

ul. Podchorążych 2

30-084 Kraków, Polska

e-mail: aswietek@up.krakow.pl 